\title{
Bioedusiana
}

http://jurnal.unsil.ac.id/index.php/bioed/index

DOI: https://doi.org/10.34289/292822

\section{PENERAPAN MODEL DISCOVERY LEARNING DENGAN PRAKTIK "ANGGIT ANGGLANG" UNTUK MENINGKATKAN HASIL BELAJAR SISWA PADA MATA PELAJARAN BIOLOGI DI SMAN 2 KOTA TASIKMALAYA Application of Discovery Learning Models with "Anggit Angglang" to Improve Student's Learning Outcomes in Biology Subjects in SMAN 2 Tasikmalaya}

Iis Suminar Rahmi ${ }^{1)}$

${ }^{1)}$ SMAN 2 Kota Tasikmalaya, J1. RE Martadinata 261 Kota Tasikmalaya, 46151 Jawa Barat Email korespondensi: rachmy.iis70@gmail.com

\begin{abstract}
Info Artikel
Sejarah Artikel:

Diterima 28 September

2019

Disetujui 15 November 2019

Dipublikasikan 1

Desember 2019

Keywords:

Hasil belajar, discovery

learning, Anggit Angglang,

Biologi, penelitian tindakan kelas

Abstrak

Tujuan penelitian ini adalah untuk mengetahui hasil belajar siswa kelas X IPA-1 SMA Negeri 2 Kota Tasikmalaya pada mata pelajaran Biologi melalui penggunaan model pembelajaran discovery learning dengan praktik "Anggit Angglang". Metode penelitian yang digunakan adalah penelitian tindakan kelas (PTK). Penelitian ini dilaksanakan dalam 2 siklus perbaikan, dan masing-masing dilakukan dalam siklus 2 pertemuan. Subjek penelitian ini adalah siswa kelas X IPA-1 SMA Negeri 2 Kota Tasikmalaya tahun 2018 pada mata pelajaran Biologi. Jumlah siswa dalam penelitian ini sebanyak 36 orang, yang terdiri dari 18 orang laki-laki dan 18 orang perempuan. Teknik pengumpulan data dalam penelitian ini dilakukan melalui kegiatan berupa: (a) perencanaan tindakan; (b) pelaksanaan tindakan; (c) pengamatan tindakan; dan (d) refleksi. Hasil penelitian menunjukkan terdapat peningkatan rata-rata skor hasil belajar dari 61,11 pada pertemuan 1 Siklus I menjadi 66,94 pada pertemuan 2 Siklus I. Kemudian, skor rata-rata hasil belajar 75,69 pada pertemuan 1 Siklus II menjadi 81,11 pada pertemuan 2 siklus II. Sementara itu, terjadi peningkatan persentase ketuntasan belajar pada pertemuan 1 siklus I ke pertemuan 2 siklus I yang masing-masing $15 \%$ dan $40 \%$. Kemudian, pada pertemuan I siklus II, persentase ketuntasan belajar berada pada posisi $65 \%$ dan mengalami peningkatan menjadi $82,50 \%$ pada pertemuan 2 siklus II. Berdasarkan hasil tersebut, maka skor hasil belajar dan persentase ketuntasan belajar selalu mengalami peningkatan pada setiap siklusnya, baik pertemuan 1 maupun pertemuan 2. Oleh karena itu, dapat disimpulkan bahwa penggunaan model pembelajaran discovery learning dengan praktik "Anggit Angglang" dapat meningkatkan hasil belajar siswa kelas X IPA-1 SMA Negeri 2 Kota Tasikmalaya pada mata pelajaran Biologi.
\end{abstract}

\begin{abstract}
The purpose of this research is to study the learning outcomes of class X IPA-1 students of SMA Negeri 2 Tasikmalaya in Biology subjects through the use of discovery learning models with the "Anggit Anggalang" practice. The research method that used is Classroom Action Research (CAR). This research was conducted in 2 repair cycles, and each conducted in 2 meeting cycles. The subjects of this research were students of class X IPA-1 SMA Negeri 2 Tasikmalaya in 2018 on Biology subjects. The number of students in this research were 36 people, consisting of 18 boys and 18 girls. The technique of collecting data in this research was carried out through activities consisting of: (a) action planning; (b) action implementation (c) action observation; and (d) reflection. The results showed that there was an increase in the average score of learning outcomes, from 61.11 at the 1st meeting of cycle I to 66.94 at the 2 nd meeting of cycle I. Then, the average score of learning outcomes at the 1st meeting of cycle II is 75.69 becames 81.11 at the 2nd meeting of cycle II. Meanwhile, there was an increase in the percentage of mastery learning at the 1st meeting of cycle I to the 2 nd meeting of cycle I, which were $15 \%$ and $40 \%$ respectively. Then, at the 1st meeting of the cycle II, the percentage of mastery learning was at $65 \%$ and increased to $82.50 \%$ at the 2 nd meeting of the cycle II. Based on these results, the score of learning outcomes and the percentage of mastery learning always increase in each cycle, both in 1st meeting and 2nd meeting. Therefore, it can be concluded that the use of learning models of discovery learning with the "Anggit Anggalang" practice can improve student learning outcomes in class X IPA-1 SMA Negeri 2 Tasikmalaya on Biology subjects.
\end{abstract}

(C) 2019 Universitas Siliwangi 
Iis Suminar Rahmi / Bioedusiana 4 (2) (2019)

\begin{tabular}{lr}
\hline Alamat korespondensi: & ISSN: 2684-7604 (online) \\
Jurusan Pendidikan Biologi FKIP Universitas Siliwangi & ISSN: 2477-5193 (print) \\
Gedung Perkantoran FKIP Lt. 3 & \\
Jalan Siliwangi No. 24 Kota Tasikmalaya 46115 & \\
HP. 08112344989 (a.n. Rinaldi Rizal Putra, M.Sc.) & \\
E-mail: bioedusiana@unsil.ac.id &
\end{tabular}




\section{PENDAHULUAN}

Pendidikan bertujuan untuk membangun kehidupan masa kini dan masa depan yang lebih baik dari masa lalu dengan berbagai kemampuan intelektual, kemampuan berkomunikasi, sikap sosial, kepedulian, dan berpartisipasi untuk membangun kehidupan masyarakat dan bangsa yang lebih baik (experimentalism and social reconstructivism) (Siegel, 2010). Pendidikan ditujukan untuk mengembangkan kecerdasan intelektual dan kecemerlangan akademik melalui pendidikan disiplin ilmu. Untuk mendapatkan pendidikan yang berkualitas dan bermutu perlu dilakukan perbaikan, perubahan dan pembaharuan dalam segala aspek yang mempengaruhi keberhasilan pendidikan. Aspek-aspek tersebut meliputi kurikulum, sarana dan prasarana, guru, siswa, serta metode pengajaran yang digunakan (Setyaningsih, 2018). Proses pembelajaran harus diupayakan dapat mengembangkan kemampuan berfikir dan keterampilan untuk mengaplikasikan dalam kehidupan sehari-hari (Mukhlisuddin, 2016) sehingga pembelajaran di kelas membutuhkan penggunaan strategi dan metode yang tepat oleh guru sebagai pengajar.

Biologi merupakan cabang sains yang ada dalam dunia pendidikan. Namun pada kenyataannya kebanyakan orang beranggapan bahwa pelajaran ini hanya berbentuk pengetahuan teoritis. Hal ini menimbulkan berkurangnya perhatian orang terhadap pelajaran tersebut. Padahal jika ditelusuri lebih jauh, Biologi tidak hanya dapat dipelajari dengan teori karena diperlukan pemahaman konsep yang benar.

Pemahaman konsep dalam mempelajarinya dapat dilakukan dengan meningkatkan kualitas proses pembelajaran, salah satunya dengan penggunaan metode yang tepat, dimana metode-metode tersebut menentukan strategi yang akan digunakan. Berbagai inovasi dilakukan dalam bidang pendidikan untuk meningkatkan kualitias sumber daya manusia Indonesia, salah satunya adalah dengan menggunakan model pembelajaran dan penumbuhan budaya literasi.

Dalam peraturan Mentri Pendidikan No. 23 tahun 2015 tentang penumbuhan budi pekerti melalui pelaksanaan beragam kegiatan rutin di sekolah, tercantum kewajiban sekolah untuk menyelenggarakan kegiatan literasi sekolah (GLS), adalah sebuah gerakan literasi di lingkungan Kementerian Pendidikan dan Kebudayaan yang merupakan bagian dari Gerakan Literasi Nasional. Gerakan literasi sekolah merupakan salah satu bentuk kesadaran pemerintah akan pentingnya membangun budaya literasi dalam dunia pendidikan supaya tercipta budaya membaca dan menulis di lingkungan sekolah sebagai upaya terwujudnya long life education. Membaca memberikan pengaruh budaya yang amat kuat terhadap perkembangan literasi peserta didik. Sayangnya, sampai saat ini prestasi literasi membaca peserta didik di Indonesia masih rendah, berada di bawah ratarata skor internasional (Disdik Jabar, 2018).

Anggit Angglang merupakan praktik dasar literasi dalam hal mengenal, memahami dan mempraktekkan pola berpikir terbuka, yang bisa dilatihkan melalui kegiatan literasi sehari-hari (Amri, 2019). Tujuannya membantu individu menguasai pola berfikir untuk mempermudah proses mengingat, memahami, menyerap dan mengaplikasikan ilmu pengetahuan dan keterampilan yang akan menjadi bekal dalam menaklukan tantangan kehidupannya. Selain itu diharapkan hasil literasi ini dapat melatih para peserta didik terampil dalam membagikan informasi yang baik dan bertanggung jawab.

Hasil belajar siswa kelas X IPA 1 SMA Negeri 2 Tasikmalaya pada mata pelajaran Biologi masih belum mencapai apa yang diharapkan. Terlihat dari nilai siswa yang mendapat nilai rata-ratanya belum mencapai Kriteria Ketuntasan Minimal (KKM) 75 dan persentase ketuntasan belum mencapai persentase ketuntasan minimal $(80 \%)$. Dari 36 orang siswa hanya 6 orang siswa yang mencapai Kriteria Keuntasan Minimal (KKM) 75, sisanya 30 orang siswa masih dibawah Kriteria Ketuntasan Minimal (70) dan belum mencapai persentase ketuntasan minimal (80\%). Faktor penyebabnya adalah pemahaman siswa terhadap suatu konsep pembelajaran masih rendah. Dengan pemahaman yang rendah maka hasil belajarpun akan rendah.

Fitriani et.al (2017) menjelaskan pembelajaran biologi hendaknya tidak lagi terlalu berpusat pada guru melainkan harus lebih berorientasi pada siswa agar terjadi peningkatan 
pemahaman peserta didik terhadap konsep Biologi.

Amri dan Ahmadi (2010) menjelaskan pengalaman belajar bagi siswa dapat diperoleh melalui rangkaian kegiatan dalam mengeksplorasi lingkungan melalui interaksi aktif dengan teman sejawat dan seluruh lingkungan belajarnya. Model pembelajaran ini dirancang khusus untuk menunjang proses belajar siswa yang berkaitan dengan guided discovery. Metode pembelajaran yang mampu mengatasi masalah tersebut adalah metode penemuan (discovery).

Perumusan masalah dalam penelitian ini antara lain bagaimanakah penggunaan model model discovery learning dengan praktik Anggit Angglang untuk meningkatkan hasil belajar siswa kelas X.IPA.1 SMA Negeri 2 Tasikmalaya pada Mata Pelajaran Biologi? Dan apakah penggunaan model discovery learning dengan praktik Anggit Angglang dapat meningkatkan hasil belajar siswa kelas X.IPA.1 SMA Negeri 2 Tasikmalaya pada Mata Pelajaran Biologi?

Berdasarkan rumusan masalah tersebut, maka tujuan penelitian ini antara lain untuk mendeskripsikan penggunaan model discovery learning dengan praktik Anggit Angglang untuk meningkatkan hasil belajar siswa kelas X.IPA.1 SMA Negeri 2 Tasikmalaya pada Mata Pelajaran Biologi dan untuk mengetahui peningkatan hasil belajar siswa kelas X.IPA.1 SMA Negeri 2 Tasikmalaya pada mata pelajaran Biologi melalui penggunaan model discovery learning dengan praktik Anggit Angglang.

\section{METODE}

Penelitian ini dilaksanakan di SMA Negeri 2 Tasikmalaya dengan subjek penelitian Kelas X.IPA.1. Waktu penelitian dilaksanakan sejak tanggal 1 Oktober 2018 sampai dengan 22 Oktober 2018.

Subjek penelitian ini adalah para siswa kelas X IPA 1 SMA Negeri 2 Tasikmalaya Kota Tasikmalaya dengan jumlah 36 orang siswa yang terdiri dari 18 orang siswa laki-laki dan 18 orang siswa perempuan. Siswa kelas ini memiliki karakteristik yang beragam, baik dari prestasi belajar maupun partisipasi orang tua dalam keberhasilan pendidikan anaknya.

Sesuai dengan karakteristiknya, rancangan penelitian tindakan kelas (PTK) ini dilaksanakan melalui 4 tahap kegiatan. Prosedur pelaksanaan penelitian ini mengikuti prinsip prinsip dasar penelitian tindakan yang telah umum dilakukan. Waseno (1994) dan Suhardjono (2007) menyatakan proses penelitian tindakan adalah suatu proses daur ulang dari perencanaan, tindakan, observasi dan refleksi (perenungan, pemikiran, dan evaluasi). Penelitian yang dilakukan direncanakan terdiri dari dua siklus dan setiap siklus terdiri atas dua pertemuan.

Data dalam PTK adalah segala bentuk informasi yang terkait dengan kondisi, proses, dan keterlaksanaan pembelajaran, serta hasil belajar yang diperoleh siswa. Data yang diperoleh yaitu data kualitatif yang berupa angka atau bilangan, baik yang diperoleh dari hasil pengukuran maupun diperoleh dengan cara mengubah data kualitatif menjadi data kuantitatif.

Data kuantitatif dianalisis secara deskriptif dengan cara:

1. Menghitung jumlah;

2. Menghitung rata-rata (rerata);

3. Menghitung nilai persentase; dan

4. Membuat grafik.

Data-data yang diperlukan dalam kegiatan penelitian ini dikumpulkan dengan menggunakan teknik pengumpulan data sebagai berikut :

1. Observasi, yaitu melakukan pengamatan secara langsung di lapangan. Observasi dilakukan oleh observer untuk mengetahui keberhasilan proses pembelajaran dengan indikator. Kemampuan mengingat fakta, kemampuan mengingat konsep, kemampuan mengingat prosedur, kemampuan mengingat prinsip, dan kemampuan menggunakan prosedur.

2. Tes tertulis, yaitu melaksanakan evaluasi sesudah kegiatan pembelajaran untuk mengetahui hasil belajar siswa. Bentuk soal berupa uraian dengan KKM 75 dan prosentase ketuntasan $80 \%$.

Data yang telah terkumpul dilakukan analisis dengan cara membandingkan pada setiap siklus apakah ada peningkatan atau tidak. Untuk hasil observasi dilakukan prosentase pada setiap hasil observasi, sedangkan pada untuk nilai tes berdasarkan kriteria ketuntasan minimal sebagai tolak ukur pencapaian keberhasilan belajar siswa pada mata pelajaran Biologi. 
Analisis dan pengolahan data dilakukan selama penelitian dari awal hingga akhir penelitian. Data diperoleh dari kumpulan instrument dan dideskrpsikan untuk diambil kesimpulannya. Adapun langkah analisis data dilakukan dengan cara sebagai berikut :

1. Penyeleksian data yaitu pemilihan data yang akurat yang dapat menjawab fokus penelitian dan memberikan gambaran tentang hasil penelitian;

2. Pengklasifikasian data yaitu pengelompokan data yang telah diseleksi, pengklasifikasian data bertujuan untuk memudahkan pengolahan data dan pengambilan keputusan berdasarkan presentase yang dijadikan pegangan; dan

3. Pentabulasian data, dilakukan setelah data diklasifikasikan berdasarkan tujuan penelitian kemudian ditabulasikan dalam bentuk tabel dengan tujuan untuk mengetahui frekuensi masing-masing alternatif jawaban yang satu dengan yang lain agar mempermudah membaca data.

Ketiga komponen tersebut dijadikan pegangan dalam meningkatkan analisis menuju pencapaian dan perbaikan pembelajaran di SMAN 2 Tasikmalaya. Dengan demikian dapat memberikan kejelasan terhadap pelaksanaan kegiatan yang dituangkan sehingga orang lain dapat membaca dengan mudah.
Peningkatan indikatornya adalah adanya peningkatan hasil belajar siswa dari kurang baik menjadi baik. Peningkatan hasil belajar mata pelajaran Bioloagi siswa kelas X IPA 1 SMA Negeri 2 Tasikmalaya melalui penggunaan model pembelajaran discovery learning dengan praktik anggit angglang indikatornya adalah nilai evaluasi siswa mencapai Kriteria Ketuntasan Minimal 75 dan persentase ketuntasan minimal mencapai $80 \%$.

\section{HASIL DAN PEMBAHASAN}

Berdasarkan hasil penelitian yang telah dilaksanakan dari dua siklus mata pelajaran Biologi diperoleh data nilai hasil evaluasi sebelum perbaikan, siklus I dan Siklus II, dapat dilihat pada Tabel 1 berikut. Berdasarkan pada Tabel 1 tersebut, dapat dilihat peningkatan nilai tertinggi, nilai terendah, nilai rata-rata hasil belajar dan persentase ketuntasan.

Rata-rata hasil belajar meningkat dari 61,11 pada pertemuan 1 Siklus I, menjadi 66,94 pada pertemuan 2 Siklus I, menjadi 75,69 pada pertemuan 1 Siklus II dan menjadi 81,11 pada pertemuan 2 siklus II.

Tabel 1. Rekapitulasi Data Hasil Evaluasi Perbaikan Siklus I dan Siklus II

\begin{tabular}{|l|l|c|c|c|c|}
\hline \multirow{2}{*}{ No } & \multirow{2}{*}{ Kriteria } & \multicolumn{2}{|c|}{ Siklus I } & \multicolumn{2}{c|}{ Siklus II } \\
\cline { 3 - 6 } & & Pert.1 & Pert.2 & Pert.1 & Pert.2 \\
\hline 1 & Nilai Tertinggi & 80 & 85 & 90 & 100 \\
\hline 2 & Nilai Terendah & 40 & 45 & 50 & 60 \\
\hline 3 & Rata-rata Kelas & 61,11 & 66,94 & 75,69 & 81,11 \\
\hline 4 & persentase Ketuntasan & $15 \%$ & $40 \%$ & $65 \%$ & $82,50 \%$ \\
\hline
\end{tabular}

Berdasarkan data tersebut, walaupun telah terjadi peningkatan pada nilai rata-rata hasil belajar kelas dari pertemuan 1 ke pertemuan 2 pada siklus I, namun penelitian baru dinyatakan berhasil pada siklus II, karena peningkatan yang diperoleh lebih signifikan. Begitu pula pada prosesntasi ketuntasan terjadi peningkatan dari $15 \%$ pada pertemuan 1 Siklus I, menjadi $40 \%$ pada pertemuan 2 Siklus 1, menjadi $65 \%$ pada petemuan 1 Siklus II dan menjadi $82,50 \%$ pada pertemuan 2. Dengan demikian berdasarakan prersentasi ketuntasan penelitian baru dinyatakan berhasil pada pertemuan 2 siklus II.

Peningkatan hasil belajar pada setiap pertemuan pada siklus I dan Siklus II, lebih jelasnya dapat dilihat pada grafik Gambar 1 berikut.

Berdasarkan pembahasan setiap siklus, maka secara keseluruhan telah terjadi peningkatan hasil belajar dari silklus 1 pertemuan 1 baik pada nilai rata-rata kelas maupun persentasi ketuntasan, dimana penelitian mencapai kriteria keberhasilan saat baik nilai 
rata-rata kelas maupuan prosentasi ketuntasan mencapai kriteria keberhasilan, 75 dan $80 \%$, yaitu pada siklus II pertemuan 2 sebesar 81,11 untuk rata-rata kelas dan $82,5 \%$ untuk persentase penilaian.

Proses perbaikan pembelajaran yang dilakukan pada siklus I, penggunaan model pembelajaran discovery learning dengan praktik anggit angglang yang digunakan kurang efektif dan hanya terpusat pada siswa yang memiliki kemampuan di atas rata-rata saja. Sedangkan pada siklus II penggunaan model pembelajaran discovery learning dengan praktik anggit angglang untuk menjelaskan materi pada pembelajaran Biologi lebih efektif, begitu pula dengan intensitas bimbingan guru terhadap siswa lebih ditingkatkan terutama pada siswa yang memiliki kemampuan kurang, sehingga siswa dapat memahami proses melalui masukan dari teman kelompok dan guru.

Model pembelajaran penemuan (discovery learning) diartikan sebagai proses pembelajaran yang terjadi ketika siswa tidak disajikan informasi secara langsung tetapi siswa dituntut untuk mengorganisasikan pemahaman mengenai informasi tersebut secara mandiri. Siswa dilatih untuk terbiasa menjadi seorang yang saintis (ilmuan). Mereka tidak hanya sebagai konsumen, tetapi diharapkan pula bisa berperan aktif, bahkan sebagai pelaku dari pencipta ilmu pengetahuan. Dalam penelitian ini, karakter model discovery learning sangat terlihat dengan meningkatnya nilai hasil belajar dalam setiap siklusnya.

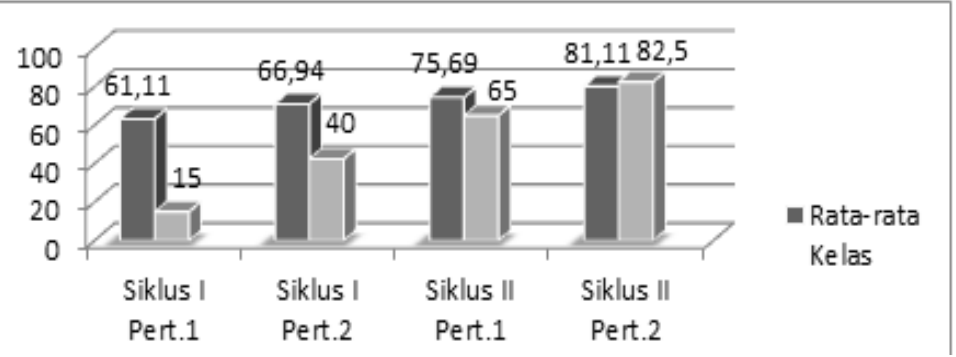

Gambar 1. Rekapitulasi Data Hasil Perbaikan Siklus I dan Siklus II

Hosnan (2014) menyatakan bahwa karakteristik discovery learning salah satunya adalah melatih siswa lebih mandiri dan kretaif. Dalam pembelajarannya siswa memiliki kesempatan untuk terlibat secara aktif dalam pembelajaran. Kenyataan menunjukan bahwa partisipasi banyak siswa dalam pembelajaran meningkat ketika proses discovery digunakan. $\mathrm{Hal}$ lainnya adalah melalui pembelajaran discovery, siswa belajar menemukan pola dalam situasi konkrit maupun abstrak, juga siswa banyak meramalkan (extrapolate) informasi tambahan yang diberikan. Pola-pola berpikir semacam ini, muncul ketika proses pembelajaran berlangsung terutama pada siklus II, nampak pada peningkatan hasil belajar yang signifikan dibandingkan pada siklus I.

Keberhasilan discovery learning pada penelitian ini, tidak terlepas dari beberapa fakta yang menunjukan bahwa keterampilanketerampilan, konsep-konsep dan prinsip-prinsip yang dipelajari melalui proses discovery lebih bermakna. Kebermaknaan pembelajaran nampak pada semakin meningkatnya nilai rata-rata hasil belajar pada setiap siklusnya, apalagi jika dibandingkan dengan proses pembelajaran sebelumnya dengan tidak menggunakan model discovery (Hosnan, 2014).

\section{SIMPULAN, SARAN, DAN REKOMENDASI}

Berdasarkan hasil penelitian dapat disimpulkan bahwa penggunaan model pembelajaran Discovery Learning dengan praktik anggit angglang dapat meningkatkan hasil belajar siswa kelas X IPA 1 SMA Negeri 2 Tasikmalaya pada mata pelajaran Biologi . Hal ini bisa dilihat dari rata-rata hasil belajar meningkat dari 61,11 pada pertemuan 1 Siklus I, menjadi 66,94 pada pertemuan 2 Siklus I, menjadi 75,69 pada pertemuan 1 Siklus II dan menjadi 81,11 pada pertemuan 2 siklus II, hasil belajar naik signifikan menjadi $82,50 \%$ dengan rata-rata kelas 
mencapai 81,11. Sementara dari prosesntasi ketuntasan terjadi peningkatan dari $15 \%$ pada pertemuan 1 Siklus I, menjadi $40 \%$ pada pertemuan 2 Siklus 1 , menjadi $65 \%$ pada petemuan 1 Siklus II dan menjadi $82,50 \%$ pada pertemuan 2.

Berdasarkan pembahasan setiap siklus, maka secara keseluruhan telah terjadi peningkatan hasil belajar dari silklus 1 pertemuan 1 baik pada nilai rata-rata kelas maupun prosentase ketuntasan, dimana penelitian mencapai kriteria keberhasilan saat baik nilai rata-rata kelas maupuan prosentase ketuntasan mencapai kriteria keberhasilan, 75 dan $80 \%$, yaitu pada siklus II pertemuan 2 sebesar 81,11 untuk rata-rata kelas dan $82,50 \%$ untuk prosentase penilaian.

Untuk perbaikan pada penelitian selanjutnya, kami memberikan saran dan rekomendasi antara lain:

1. Penggunaan model pembelajaran discovery learning dengan praktik anggit angglang dapat meningkatkan keterlibatan siswa dalam proses pembelajaran dalam menemukan dan memecahkan masalah dan dapat diimplementasikan dalam mata pelajaran lain;

2. Kepala sekolah memfasilitasi sarana dan prasarana untuk proses pembelajaran dengan menggunakan model discovery learning dengan praktik anggit angglang agar hasil belajar siswa menjadi maksimal;

3. Rekan-rekan guru yang lain dapat berkolaborasi dalam penelitian tindakan kelas dalam mengembangkan strategi dan metode yang bervariasi sehingga siswa merasa lebih bermakna dalam belajarnya;

4. Orang tua murid turut memberkan motivasi kepada anaknya dalam belajar Biologi terutama dalam membimbing bagaimana cara menyelesaikan masalah Biologi; dan

5. Pihak pengawas pembina cabang dinas pendidikan wilayah XII selaku pengawas dan supervisor lebih berupaya juga memberikan dukungan mengupayakan PTK untuk peningkatan kualitas pendidikan di kegiatan pembinaan atau MGMP secara resmi.

\section{UCAPAN TERIMA KASIH}

Ucapan terima kasih ditujukan kepada Kepala Sekolah beserta rekan-rekan guru di SMA Negeri 2 Tasikmalaya yang telah memberikan dukungan dan motivasi untuk terus berjuang dalam rangka peningkatan mutu pendidikan.

\section{DAFTAR PUSTAKA}

Amri, S. (2019, 02 Maret). Menumbuhkan Budaya Literasi Keluarga melalui Program Anggit Angglang. Diambil dari https://www.guneman.com/2019/03/me numbuhkan-budaya-literasi-keluarga.html

Amri dan Ahmadi. 2010. Konstruksi Pengembangan Pembelajaran. Prestasi Pustaka. Jakarta.

Dinas Pendidikan Provinsi Jawa Barat. (2018). Pembelajaran Berbasis Literasi Melalui Praktik Anggit Angglang. Panduan Pelatihan.

Huda, M. (2013). Model-Model Pengajaran Dan Pembelajaran. Yogyakarta: Pustaka Pelajar.

Komalasari, K. (2010). Pembelajaran Kontekstual: Konsep dan Aplikasi. Refika Aditama. Bandung.

Mukhlisuddin. (2016). Pengembangan Berpikir Kritis pada Siswa Melalui Pemberian Tugas dengan Tingkat Kesukaran Berjenjang. Edumatica, 6(2): pp. $70-80$.

Setyaningsih, S. (2018). Pengelolaan Sarana Prasarana dalam Implementasi Kurikulum Pendidikan Guru Sekolah Dasar: Sebuah Studi Kasus di Universitas Negeri Semarang. Jurnal Managemen Pendidikan, 13(1): pp. $62-71$.

Suhardjono. (2007). Penelitian Tindakan Kelas. Bumi Aksara. Jakarta

Siegel, H. (2010). The Oxford Handbook of Philosophy of Education. UK: Oxford University Press.

Sudjana, N (2003). Penilaian Hasil Proses, Bandung, Remaja Rosdakarya.

Sudjana, N. (2005). Metode Statistika. Bandung: PT Tarsito Bandung.

Trianto. (2009). Mendesain Model Pembelajaran Invatif-Progresif. Jakarta : Kencana Prenada Group. 
Iis Suminar Rahmi / Bioedusiana 4 (2) (2019) 